Larsen, J.E., G.F. Warren, and R. Langston. 1958. Studies of phosphorus availability in organic soils. Soil Sci. Soc. Am. Proc. 22:336-339.

LOTAC II. 1990. Final report of the Lake Okeechobee Technical Advisory Council submitted to the Governor of the State of Florida, the Secretary of the Florida Department of Environmental Regulation, and the Governing Board of the South Florida Water Management District, Tallahassee, FL.

Mead, G.P. and J.C.P. Chen. 1977. Cane Sugar Handbook. 10th ed. John Wiley \& Sons, New York, NY.

Murphy, J. and J.P. Riley. 1962. A modified single solution method for the determination of phosphate in natural waters. Anal. Chem. Acta 27:31-36.

SAS Institute. 1987. SAS/STAT Guide for Personal Computers. Version 6. Statistical Analysis System Institute, Cary, NC.

Watanabe, F.S. and S.R. Olsen. 1965. Test of ascorbic acid method for determining phosphorus in water and $\mathrm{NaHCO}_{3}$ extracts from soil. Soil Sci. Soc. Am. Proc. 19:677678. 


\title{
Effects of Liming, Green Manuring, and Phosphate Addition on Electrochemical Attributes of an Oxisol from Central Brazil
}

\author{
J. F. Dynia ${ }^{\mathrm{a}, 1}$ and O. A. Camargo ${ }^{\mathrm{b}}$ \\ ${ }^{a}$ CNPMA-EMBRAPA, Caixa Postal 69, Jaguariúna (SP), Brazil \\ 'Instituto Agronômico, Caixa Postal 28, CEP 13001-970, Campinas (SP), \\ Brazil
}

\section{ABSTRACT OK}

Highly weathered tropical soils are characterized by having a predominantly variable charge. Many management practices commonly used in the exploitation of these soils (e.g., liming, phosphate application, and manuring) are known to modify their electrical charge and the sorption/desorption behavior of cations and anions. This process is, at least, partially governed by the charges existing in the soil system. Available information on this subject comes mainly from short-term laboratory and greenhouse experiments. There is a lack of data regarding the cumulative and long-term effects of those practices used at farm-scale levels and on the dynamics and availability of nutrients to the plants under field conditions. In the present work, changes in some electrochemical attributes of a variable charge soil (Oxisol) were studied, as influenced by treatments with phosphate + green manure (Cajanus cajan), phosphate + lime, and phosphate + lime + green manure, applied

${ }^{1}$ Corresponding author. 
during a six-year period. In this period, rice, bean, wheat, or corn, were grown in seventeen successive crops. Phosphate (total $334 \mathrm{ppm} \mathrm{P)} \mathrm{and}$ phosphate + lime (total $5.5 \mathrm{t} \mathrm{ha}^{-1}$ ) were shown to increase net electric charge and soil cation exchange capacity (CEC) at the field $\mathrm{pH}$, and not to affect zero point of charge (ZPC), CEC at $\mathrm{pH} 7.0$, or anion exchange capacity (AEC) of the soil at the field $\mathrm{pH}$. The effects of phosphate + lime were more pronounced than those of phosphate alone. Green manure (total $16 \mathrm{t} \mathrm{ha}^{-1} \mathrm{dry}$ matter), associated to crop residues and phosphate or phosphate + lime, did not influence electrochemical properties.

\section{INTRODUCTION}

Highly weathered soils of tropical region, as the Oxisol order, present variable charge due to the predominance in its colloidal fraction of iron $(\mathrm{Fe})$ and aluminum (Al) oxides and hydroxides and low activity clays like kaolinite. These minerals are amphoteric and their surface electrical charges are controlled mainly by adsorption and desorption of $\mathrm{H}^{+}$and $\mathrm{OH}^{-}$(Raij and Peech, 1972). In these soils, positive and negative charges coexist in natural conditions. Once the relative distribution of those charges may vary intensely with $\mathrm{pH}$ and ionic concentration of the soil solution, any external component introduced in the system that modify those attributes will change the soil anion and cation retention capacity.

One important parameter used to describe the electrochemical behavior of variable charge soil is the point of zero charge (Uehara and Gillman, 1980). Although a property relatively stable, specific adsorption of anion (Uehara and Keng, 1975) and the soil organic matter (Raij and Peech, 1972; Moraes et al., 1976) may significantly modify its value.

Tropical soils frequently have to be limed in order to decrease the Al toxicity, add calcium (Ca), and increase crop yields. Several authors (Raij and Peech, 1972; Smyth and Sanchez, 1980; Bolan et al., 1988; Naidu et al., 1990) working on different variable charge soils, verified that the net negative charge increased as $\mathrm{pH}$ increased due to lime. Some of them (Raij and Peech, 1972; Naidu et al., 1990 ) indicated that the increase in negative and decrease in positive charge was not proportional.

There is generalized phosphorus deficiency in the tropics in which phosphorus (P) fertilization is an obligatory practice to obtain good grain yields. In addition to its function as a nutrient, phosphate applied in these very weathered soils may increase soil CEC (Mekaru and Uehara, 1972; Wann and Uehara, 1978; Gillman and Fox, 1980) due to the displacement of hydroxyls and/or water molecules which are coordinated to $\mathrm{Fe}$ or $\mathrm{Al}$ of the sesquioxides surface, thereby increasing their negative charge. Although the increase in CEC due to phosphate application to those soils may be significant, fertilizer applications are generally not economical (Mekaru and Uehara, 1972; Gillman and Fox, 1980). On the other hand, P- 
adsorption may decrease the anion exchange capacity due to reduction of the positive charge of the soil colloids.

Organic matter is the main component responsible for negative charge development in soils with variable charge. It may represent up to $90 \%$ of the total soil CEC (Raij, 1969). Besides its contribution to the increase in CEC it also influences the soil ZPC (Raij and Peech, 1972) tending to displace it to lower values.

The objective of the present work was to study the influence of liming, phosphate application, and green manuring on some electrochemical attributes of an Oxisol in actual agricultural field conditions.

\section{MATERIALS AND METHODS}

\section{Soil Samples}

The soil used in this study was an Oxisol (clayey dark red latosol) located in Santo Antonio do Goiás County, in the Goiás State, Brazil. It is geographically and economically representative of the Cerrado region.

Samples from depths of 0-20, 20-40, and 40-60 cm were collected in April 1991 from field experiment, conducted from November 1982 through July 1989. Samples from each treatment and layer were composed of eight subsamples (two for each replicate) collected in small pits opened in locations chosen randomly inside each plot. The subsamples were air dried and passed through a 2-mm sieve. During that period, rice, bean, wheat, or corn, were grown as seventeen successive crops. From July 1989 through April 1991 the plots were fallowed. The plots selected in the experiment for this study were check (T), phosphate (P), phosphate + green manure (Cajanus cajan) (Pgm), phosphate + lime (Pca), and phosphate + lime + green manure (Pcagm). Phosphate fertilization corresponded to $90 \mathrm{~kg}$ of $\mathrm{P}_{2} \mathrm{O}_{5}$ from MAP in each cultivation period $\left(1,500 \mathrm{~kg} \mathrm{ha}^{-1}\right.$ of $\mathrm{P}_{2} \mathrm{O}_{5}$ for the entire six-year period). It was applied as $5.5 \mathrm{t} \mathrm{ha}^{-1}$ dolomitic limestone divided in one $2.5 \mathrm{tha}^{-1}$ rate in 1982 before the first growing period and another rate of 3.0 $t$ ha $^{-1}$ in 1985 between the ninth and tenth cropping period. Lime was broadcast and plow incorporated. Green manure was applied at a rate of $16 \mathrm{tha}^{-1}$ dry weight.

\section{Electrochemical Attributes}

The soil ZPC of the samples was measured using the potentiometric titration curves essentially as described by Raij and Peech (1972). The net electric charge at $\mathrm{pH}$ different from the $\mathrm{PZC}$ was estimated by interpolation of the titration curve according to the desired electrolyte concentration. The chosen concentration was as near as the ionic strength of the soil solution, estimated here by the Gillman and Bell (1978) procedure. The method by Gillman (1979) was chosen for the determination of CEC and AEC at natural soil $\mathrm{pH}$ condition and $\mathrm{CEC}$ at $\mathrm{pH} 7.0$ was measured using $1 \mathrm{~N} \mathrm{Ca}$ and sodium acetate at $\mathrm{pH} 7.0$ (Camargo et al., 1986). 
TABLE 1. Zero point of charge of the several soil depths affected by treatments.

\begin{tabular}{cccccc}
\hline & \multicolumn{5}{c}{ ZPC } \\
\cline { 2 - 6 } $\begin{array}{c}\text { Soil depth } \\
\text { cm) }\end{array}$ & Check & P & Pgm & Pca & Pcagm \\
\hline $0-20$ & 3.7 & 3.5 & 3.5 & 3.5 & 3.5 \\
$20-40$ & 3.8 & 3.8 & 3.7 & 3.8 & 3.8 \\
$40-60$ & 4.6 & 4.5 & 4.3 & 4.4 & 4.4 \\
\hline
\end{tabular}

${ }^{\text {aP }}=$ phosphate $\left(1,500 \mathrm{~kg} \mathrm{ha}^{-1}, \mathrm{P}_{2} \mathrm{O}_{5}\right), \mathrm{Pgm}=$ phosphate plus green manure (16 tha $\mathrm{t}^{-1}$ dry matter), Pca=phosphate plus lime (5.5 t $\left.h^{-1}\right)$, Pcagm=phosphate plus lime plus green manure.

\section{RESULTS AND DISCUSSION}

\section{Point of Zero Charge}

Table 1 shows the values of ZPC for the three depths and five treatments obtained from the crossing point of the titration curves. These values are similar to those obtained for other Brazilian soils (Raij and Peech, 1972; Moraes et al., 1976). The ZPC increased with depth from $3.7 / 3.8$ to $4.3 / 4.6$ in the $0-20-$ and $20-40-\mathrm{cm}$ and $40-60-\mathrm{cm}$ depths, respectively. That increase was due to the decrease of the organic matter content once there is a negative correlation between those two attributes (Siqueira et al., 1990). Apparently there were no significant differences among treatments in each layer, which shows that liming, phosphate fertilization, and green manuring at the applications used did not affect the ZPC value in the Oxisol studied. This observation was different from the data obtained by Wann and Uehara (1978) and Laverdiere (1982) who found decreasing values of ZPC with phosphate application. One cause of this difference may have been that in those studies, P was applied both in the laboratory and greenhouse experiments at one time and ZPC was measured after a short period of time. In the present study, a low amount of P (55.7 ppm) was applied each year during the six years of the experiment and ZPC was measured following a 21 months fallow period after the end of the experiment. It should be stressed that Wann and Uehara (1978) did not find any change in the $\mathrm{ZPC}$ at low $\mathrm{P}$ concentration which could be compared to the present case.

Green manure application also did not alter the ZPC (Table 1). Although organic matter tends to decrease ZPC, there is no certainty that increasing SOM through management practices may decrease the ZPC (Sanchez, 1976). Siqueira et al. (1990) observed no correlation between organic carbon added in an Oxisol and 
TABLE 2. Net electric charge of the soil samples in the five treatments, at three $\mathrm{pH}$ values.

\begin{tabular}{|c|c|c|c|c|c|}
\hline \multirow[b]{3}{*}{$\mathrm{pH}$} & \multicolumn{5}{|c|}{ Net electric charge } \\
\hline & \multicolumn{5}{|c|}{-a.nonents ${ }^{\mathrm{a}}$} \\
\hline & Check & $\mathrm{P}$ & Pgm & Pca & Pcagm \\
\hline & \multicolumn{5}{|c|}{$0-20 \mathrm{~cm}$} \\
\hline 4.5 & -0.2 & -0.3 & -0.4 & -0.4 & -0.4 \\
\hline field $\mathrm{pH}$ & $\begin{array}{l}-0.4 \\
(5.3)^{b}\end{array}$ & $\begin{array}{l}-0.7 \\
(5.4)\end{array}$ & $\begin{array}{l}-0.8 \\
(5.6)\end{array}$ & $\begin{array}{l}-0.9 \\
(5.8)\end{array}$ & $\begin{array}{l}-0.9 \\
(5.9)\end{array}$ \\
\hline 6.5 & \multicolumn{4}{|c|}{$20-40 \mathrm{~cm}$} & -1.5 \\
\hline 4.5 & -0.4 & -0.4 & -0.4 & -0.3 & -0.3 \\
\hline field $\mathrm{pH}$ & $\begin{array}{l}-0.7 \\
(5.2)\end{array}$ & $\begin{array}{l}-0.6 \\
(5.3)\end{array}$ & $\begin{array}{l}-0.6 \\
(5.1)\end{array}$ & $\begin{array}{l}-0.5 \\
(5.5)\end{array}$ & $\begin{array}{l}-0.6 \\
(5.7)\end{array}$ \\
\hline 6.5 & \multicolumn{5}{|c|}{$40-60 \mathrm{~cm}$} \\
\hline 4.5 & +0.1 & 0.0 & 0.0 & -0.1 & 0.0 \\
\hline field $\mathrm{pH}$ & $\begin{array}{r}-0.2 \\
(5.3)\end{array}$ & $\begin{array}{l}-0.2 \\
(5.3)\end{array}$ & $\begin{array}{l}-0.2 \\
(5.5)\end{array}$ & $\begin{array}{l}-0.2 \\
(5.4)\end{array}$ & $\begin{array}{l}-0.3 \\
(5.6)\end{array}$ \\
\hline 6.5 & -0.3 & -0.5 & -0.5 & -0.5 & -0.5 \\
\hline
\end{tabular}

aP=phosphate $\left(1,500 \mathrm{~kg} \mathrm{ha}^{-1}, \mathrm{P}_{2} \mathrm{O}_{5}\right), \mathrm{Pgm}=$ phosphate plus green manure ( $16 \mathrm{t} \mathrm{ha}^{-1}$ dry matter), $\mathrm{Pca}=$ phosphate plus lime $\left(5.5 \mathrm{tha}^{-1}\right)$, Pcagm=phosphate plus lime plus green manure.

bFigures in brackets represent the $\mathrm{pH}$ of the soil samples taken at field conditions for each treatment and depth.

the $\mathrm{ZPC}$ and concluded that adding green manure or crop residue did not affect the $\mathrm{ZPC}$ for several years.

\section{Net Electric Charge}

Once the ionic strength of the soil solution varied from $2.11 \times 10^{-4} \mathrm{M}$ in the check treatment in the $40-60-\mathrm{cm}$ layer to $10.49 \times 10^{-4} \mathrm{M}$ in the Pcagm treatment in the 0 20 -cm layer, the $0.001 \mathrm{~mol} \mathrm{~L}^{-1}$ in $\mathrm{KCl}$ titration curve was used to evaluate the net electric charge (Table 2). The charges were predominantly negative. Just in the 40-60-cm layer at $\mathrm{pH} 4.5$ the net charge oscillated around $0.00 \mathrm{cmol}_{\mathrm{c}} \mathrm{kg}^{-1}$ indicating a balance between net negative and net positive charge. There was a trend of decreasing negative charge as depth increased independently of the $\mathrm{pH}$ and probably related to SOM decrease. It may also be observed that net negative 
TABLE 3. The cation exchange capacity and anion exchange capacity at field soil $\mathrm{pH}$ (CEC nat., AEC nat.), and cation exchange capacity at pH 7.0 (CEC 7.0) for the three soil depths and five treatments.

\begin{tabular}{llll}
\hline Treatments $^{\mathrm{a}}$ & CEC nat. & CEC 7.0 & AEC nat. \\
\hline & $\ldots$ & \multicolumn{2}{c}{$0-20 \mathrm{~cm}$} \\
\cline { 2 - 4 } Check & 4.5 & 7.8 & 0.16 \\
P & 4.8 & 8.2 & 0.14 \\
Pgm & 4.6 & 8.3 & 0.16 \\
Pca & 5.6 & 7.8 & 0.15 \\
Pcagm & 5.5 & 8.0 & 0.20 \\
& & $20-40 \mathrm{~cm}$ & \\
Check & 4.4 & 6.6 & 0.30 \\
P & 4.4 & 6.7 & 0.24 \\
Pgm & 4.5 & 6.6 & 0.26 \\
Pca & 4.6 & 6.4 & 0.22 \\
Pcagm & 4.7 & 6.5 & 0.22 \\
& & $40-60 \mathrm{~cm}$ & \\
Check & 4.4 & 4.6 & 0.24 \\
P & 4.3 & 4.8 & 0.28 \\
Pgm & 4.4 & 4.7 & 0.24 \\
Pca & 4.3 & 4.8 & 0.27 \\
Pcagm & 4.4 & 4.6 & 0.27 \\
\hline
\end{tabular}

aP=phosphate $\left(1,500 \mathrm{~kg} / \mathrm{ha}^{-1}, \mathrm{P}_{2} \mathrm{O}_{5}\right), \mathrm{Pgm}=$ phosphate plus green manure (16 tha $\mathrm{t}^{-1}$ dry matter), $\mathrm{Pca}=$ phosphate plus lime (5.5 $\left.\mathrm{t} \mathrm{ha}^{-1}\right)$, $\mathrm{Pcagm}=$ phosphate plus lime plus green manure.

charge increased with $\mathrm{pH}$ and decreased from the field $\mathrm{pH}$ in each layer. This demonstrated a dependence of the $\mathrm{CEC}$ to $\mathrm{pH}$ variations.

All treatments increased the negative charge $0.4 \mathrm{cmol}_{\mathrm{c}} \mathrm{kg}^{-1}$ in average compared to the control. Although this is a small value for this type of low activity soil, it is significant, because it represents an increase of 100\%. Smyth and Sanchez (1980) obtained similar results with a similar soil in a greenhouse and laboratory experiment. As in our study, they verified a more significant increase when $\mathbf{P}$ fertilization was associated with liming. The green manure seems not to affect the negative charges.

\section{Ion Exchange Capacity}

The CEC and $\mathrm{AEC}$ at the soil field $\mathrm{pH}$ and at $\mathrm{pH} 7.0$ is recorded in Table 3. Parfitt (1980) described an increase in 50\% of CEC when liming a variable charge 
soil from $\mathrm{pH} 5$ to 6 . A similar trend was demonstrated here for the $0-20-\mathrm{cm}$ depth increment, where an increase in $0.5 \mathrm{pH}$ units resulted in a $0.7 \mathrm{cmol}_{\mathrm{c}} \mathrm{kg}^{-1}$ increase in CEC. Phosphate fertilization alone showed little tendency to increase CEC at field $\mathrm{pH}$, even though the values found were close to those obtained by Sanchez and Uehara (1980). They found CEC values of 0.1-0.2 $\mathrm{cmol}_{\mathrm{c}} \mathrm{kg}^{-1}$ per $100 \mu \mathrm{g} \mathrm{g}^{-1}$ of $\mathrm{P}$ added. The CEC at field $\mathrm{pH}$ was not affected by the treatments in the 20-40and 40-60-cm depths nor was the $\mathrm{CEC}$ at $\mathrm{pH} 7.0$ affected by treatments and depths studied.

The AEC at the original soil $\mathrm{pH}$ varied from $0.14 \mathrm{cmol}_{\mathrm{c}} \mathrm{kg}^{-1}$ in the $\mathrm{P}$ treatment in the $0-20-\mathrm{cm}$ depth to $0.30 \mathrm{cmol}_{\mathrm{c}} \mathrm{kg}^{-1}$ in the check in the $20-40-\mathrm{cm}$ depth. This variation is comparable to those obtained by Smyth and Sanchez (1980) for a similar Oxisol in the Brazil Central Plateau. Although the differences may be great in a relative comparison they are small in absolute values and may not reflect the actual differences among the treatments. The intrinsic difficulties of AEC determination resulted in considerable errors at low values. In this study, no treatment of any considered significantly affected the soil AEC.

\section{ACKNOWLEDGMENTS}

The authors wish to thank the National Council for Scientific and Technological Development (CPNq) from Brazil for research fellowships.

\section{REFERENCES}

Bolan, N.S., J.K. Syers, R.W. Tillman, and D.R. Scotter. 1988. Effect of liming and phosphate additions on sulfate leaching in soils. J. Soil Sci. 39:493-504.

Camargo, O.A., A.C. Moniz, J.A. Jorge, and J.M.A.S. Valadares. 1986. Métodos de análise química, mineralógica e física de solos do Instituto Agronômico de Campinas. Campinas, Instituto Agronômico (Boletim Técnico, 106).

Gillman, G.P. 1979. A proposed method for the measurement of exchange properties of high-weathered soils. Australian J. Soil Res. 17:129-141.

Gillman, G.P. and L.L. Bell. 1978. Soil solution studies on weathered soil from tropical North Queensland. Australian J. Soil Res. 16:67-77.

Gillman, G.P. and R.L. Fox. 1980. Increases in cation exchange capacity of variable charge soils following superphosphate applications. Soil Sci. Soc. Am. J. 44:934-938.

Laverdiere, M.R. 1982. Effects of phosphate additions on the charge properties of a podzolic B horizon. Canadian J. Soil Sci. 62:519-525.

Mekaru, T. and G. Uehara. 1972. Anion adsorption in ferruginous tropical soils. Soil Sci. Soc. Am. Proc. 36:296-300. 
Moraes, F.I., A.L. Page, and L.J. Lund. 1976. The effect of pH, salt concentration and nature of electrolytes on the charge characteristics of Brazilian tropical soils. Soil Sci. Soc. Am. J. 40:521-527.

Naidu, R., J.K. Syers, R.W. Tillman, and J.H. Kirkman. 1990. Effect of liming and added phosphate on charge characteristics of acid soils. J. Soil Sci. 41:157-164.

Parfitt, R.L. 1980. Chemical properties of variable charge soils. pp. 167-194. In: B.K.G. Theng (ed.), Soils with Variable Charge. New Zealand Society of Soil Science, Lower Hutt, New Zealand.

Raij, B. van. 1969. A capacidade de troca de cátions das frações orgânica e mineral em solos. Bragantia 28:85-112.

Raij, B. van and M. Peech. 1972. Electrochemical properties of some Oxisols and Alfisols of the tropics. Soil Sci. Soc. Am. Proc. 36:587-593.

Sanchez, P.A. 1976. Properties and Management of Soils in the Tropics. John Wiley \& Sons, New York, NY.

Sanchez, P.A. and G. Uehara. 1980. Management considerations for acid soils with high phosphorus fixation capacity. pp. 471-509. In: F.E. Khasawneh, E.C. Sample, and E.J. Kamprath (eds.), The Role of Phosphorus in Agriculture. American Society of Agronomy, Madison, WI.

Siqueira, C., J.R. Leal, A.C.X. Velloso, and G.A. Santos. 1990. Eletroquímica de solos tropicais de carga variável. II. Quantificação do efeito da matéria orgânica sobre o ponto de carga zero. R. bras. Ci. Solo 14:13-17.

Smyth, T.J. and P.A. Sanchez. 1980. Effects of lime, silicate and phosphorus application to an Oxisol on phosphorus sorption and ion retention. Soil Sci. Soc. Am. J. 44:500505 .

Uehara, G. and G.P. Gillman. 1980. Charge characteristics of soils with variable and permanent charge minerals. I. Theory. Soil Sci. Soc. Am. J. 44:250-255.

Uehara, G. and J. Keng. 1975. Management implications of soil mineralogy in Latin America. pp. 351-363. In: E. Bornemiza and A. Alvarado (eds.), Soil Management in Tropical America. North Carolina State University, Raleigh, NC.

Wann, S.S. and G. Uehara. 1978. Surface charge manipulation in constant surface potential colloids. I. Relation to sorbed phosphorus. Soil Sci. Soc. Am. J. 42:565-570. 


\title{
Effect of Treated Sewage Water on the Concentration of Certain Nutrient Elements in Date Palm Leaves and Fruits
}

\author{
Mahdi Osman El Mardi, ${ }^{a}$ S. B. Salama, ${ }^{\text {b }}$ E. C. Consolacion, ${ }^{a}$ \\ and Mohamed Al-Solomi
}

${ }^{a}$ Department of Agronomy, Horticulture, Entomology and Plant Pathology, College of Agriculture, Sultan Qaboos University, P.O. Box 34, Al-Khod 123, Sultanate of Oman

${ }^{\mathrm{b}}$ Department of Chemistry, College of Science, Sultan Qaboos University, P.O. Box 36, Al-Khod 123, Sultanate of Oman

\begin{abstract}
Leaflet and fruit samples were collected from 9-year old palms irrigated with potable water and treated sewage water from two locations (the University and the city sewage effluent plant). After drying, ashing, and dissolution of ash by $\mathrm{HCl}$, calcium $(\mathrm{Ca})$, and magnesium $(\mathrm{Mg})$ concentrations were determined by atomic absorption photometry; sodium $(\mathrm{Na})$, and potassium (K) by flame spectrophotometry and chlorine $(\mathrm{Cl})$ by titration. Results of the present study were then compared with those of 1993 . Unlike the 1993 results, $\mathrm{K}, \mathrm{Ca}, \mathrm{Mg}$, and $\mathrm{Na}$ concentrations did not show any significant differences in leaves or fruits. Potassium, $\mathrm{Ca}$, and $\mathrm{Mg}$ in leaves and fruits irrigated with three types of water in 1995 showed higher concentrations than in 1993. Sodium was lower in leaves and fruits during 1995 than 1993 when treated sewage water was used, but with potable water it was higher in leaves and lower in fruits. The increase in $\mathrm{K}, \mathrm{Ca}$, and $\mathrm{Mg}$ and the reduction in $\mathrm{Na}$ were
\end{abstract}




\section{Embrapa}

\section{DEVOLUÇÃO DE TRABALHO COM PARECER CIENTÍFICO 97059}

IImo(a). Sr(a):

Dr(a). José Flavio Dynia

Embrapa-CNPMA

Jaguariúna, SP

Prezado(a) Senhor(a),

Encaminhamos-lhe o trabalho intitulado: "Retenção de nitrato num solo de carga variável, influenciada por adubação fosfatada e calagem", que recebeu em nossos arquivos o $n^{\circ} 97059$, de sua autoria.

Junto com o trabalho mencionado, remetemos-lhe também o PARECER da Assessoria Científica. Seu artigo está indicado para publicação como NOTA CIENTífICA (Introdução, Material e Métodos, Resultados e Discussão e Conclusões agrupados em um único capítulo; não há Termos para Indexação; Resumo com no máximo 100 palavras; artigo com no máximo 8 páginas). Solicitamos que sejam feitos os ajustes $e$ as correções indicadas pela Assessoria. A versão corrigida deve chegar à secretaria da revista dentro do prazo de 30 dias, a contar da data desta correspondência. Solicitamos ainda que seja apresentada justificativa fundamentada para a rejeição de alguma sugestão.

Rogamos-lhe devolver-nos a cópia do trabalho que ora lhe estamos enviando, para facilitar a verificação da aceitação das sugestões da Assessoria Científica.

A versão corrigida deverá ser enviada em disquete (3 1/4), preferencialmente nos programas: MICROSOFT WORD 5.0 FOR DOS, MICROSOFT WORD 5.5 FOR DOS OU MICROSOFT WORD 2.0/6.0 FOR WINDOWS, e uma cópia impressa EM ESPAÇO DUPLO com tinta negra ou azul-escura.

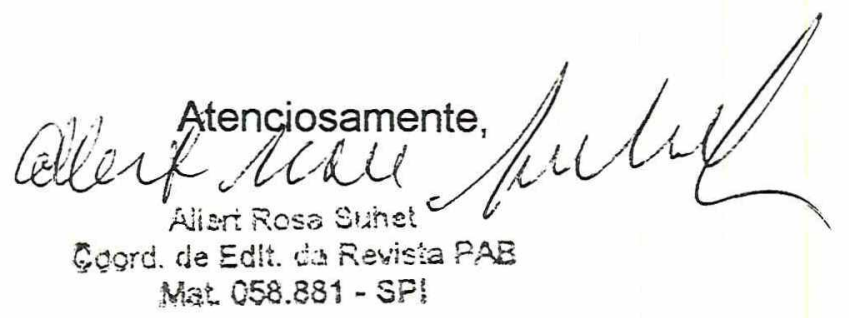
e do Abastecimento
SAIN Parque Rural - Final Av. W/3 Norte. Brasilia, DF
Tel: (061) $348-4155$ $348-4420$

$348-4162$ $348-4230$ 